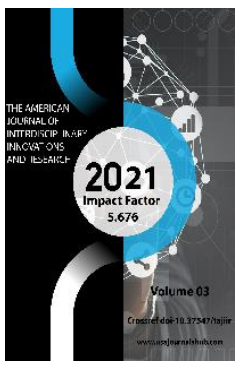

Journal Website: https://theamericanjou rnals.com/index.php/ta jiir

Copyright: Original content from this work may be used under the terms of the creative commons attributes 4.0 licence.

\section{Hygienic Effect Of The Drapery Of Children's Clothes}

Turdiyev Maxmudjon

Senior Lecturer, Department Of Light Industry Technologies and Equipment, Fergana Polytechnic Institute, Fergana, Uzbekistan

Yuldasheva Dildora

Assistant, Department Of Light Industry Technologies and Equipment, Fergana Polytechnic Institute, Fergana, Uzbekistan

\title{
ABSTRACT
}

Today, the youth, whose education process has been developing, need to be prepared for the demands of society is the main purpose. The pedagogue's experience, knowledge and personality play a big role in obsessed knowledge of youth, morality, tradition, getting learned culture, ability and developing worldwide and getting the appropriate place in society during the practical experience. In addition, developing the problem-solving abilities of the young, in the modern world, is the main responsibility of the pedagogue. For this, pedagogues should have their creative ways of teaching and the ability to react positively to the increasingly changing world. This article explains the range of clothes for pre-school children, draperies mechanical features, estimating the saving heat character of children's clothes.

\section{KEYWORDS}

Cotton, Floss, Silk, Wool, Knit, Accessories, Decorations, Clothing Culture.

\section{INTRODUCTION}

The cloth is human's property. Today, needing of our nation's, especially, youths' need is increasing highly. So, the main purpose is satisfying this increasing need with products which made in our country. Nowadays, customers' need for textile products is increasing day by day [1-3].

So, providing our internal markets with our own made high-qualified products and levelling up our countries export power, 
clearly, making textile products competitive to internal and external company's products are really important [4-7]. Because of effectively using the making opportunities, the number of clothes producing factors, family businesses are multiplying. Because of our nation is child care, especially, often will be some illnesses during the infancy, our nation really cares about our children's clothes. Maybe, for this reason, we often see some kind of traditions on children's clothes. Lots of children's clothes' design was based on kinds tradition, for protecting them from ghosts or unfamiliar people [8-1]. For expertising children's clothes need to be given 1 square meter of drapery of top cover part, liquid storage layer and its internal cover and also a ready cloth.

\section{MATERIALS AND METHODS}

Children's cloth could include cotton, floss, silk, wool (natural) and artificial or synthetic. Threads for making draperies are the following: turned and strong, or soft and fluffy. The material can consist of drapery or knitwear. When any drapery is used for children's cloth, its thickness, weight, porosity, the conductivity of air and steam, hygroscopic, water conductivity and conductivity of heat qualities should be taken into account. Based on these qualities, drapery's structure will be clarified with its air conductivity and size. Underwear of children, o to 3 years old, must be prepared from soft natural materials ( silk, cotton and viscose) [11-14]. The mechanical characters of draperies show react of material to internal and external powers.

These powers are different, big or small, or can be disposable and re-appearable. As a result, the material has flexible, distension or torsion deformations. In sewing materials, there often will be distension deformations. Mechanical features include ripping force, lengthening in distension, act done in ripping, relative ripping force and others. 

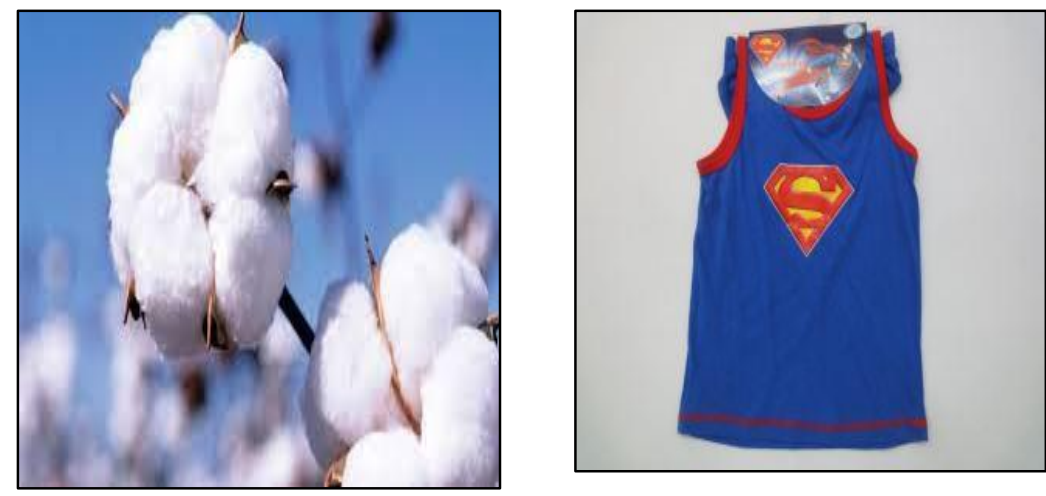

Figure 1. Cotton and cotton-made children's cloth
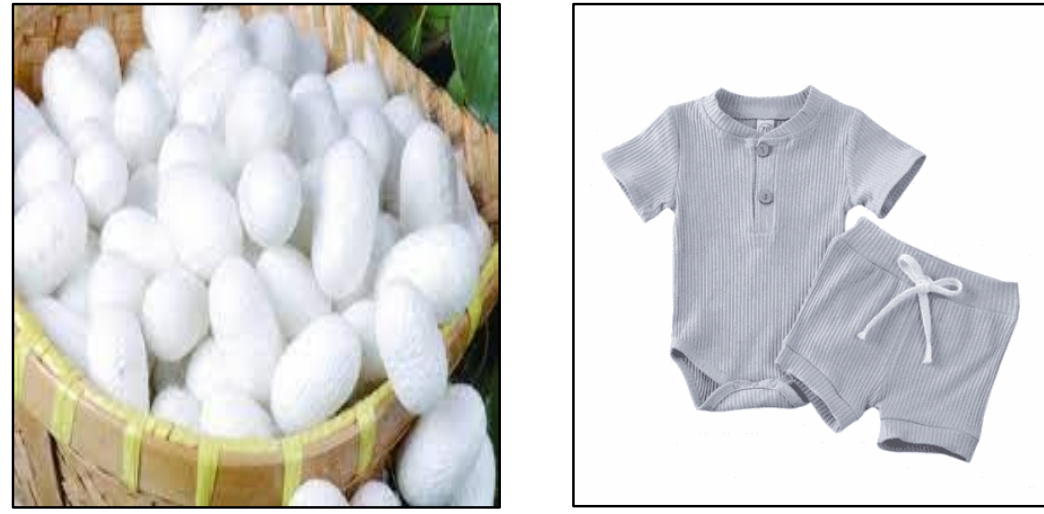

Figure 2. Silk and silk-made children's cloth
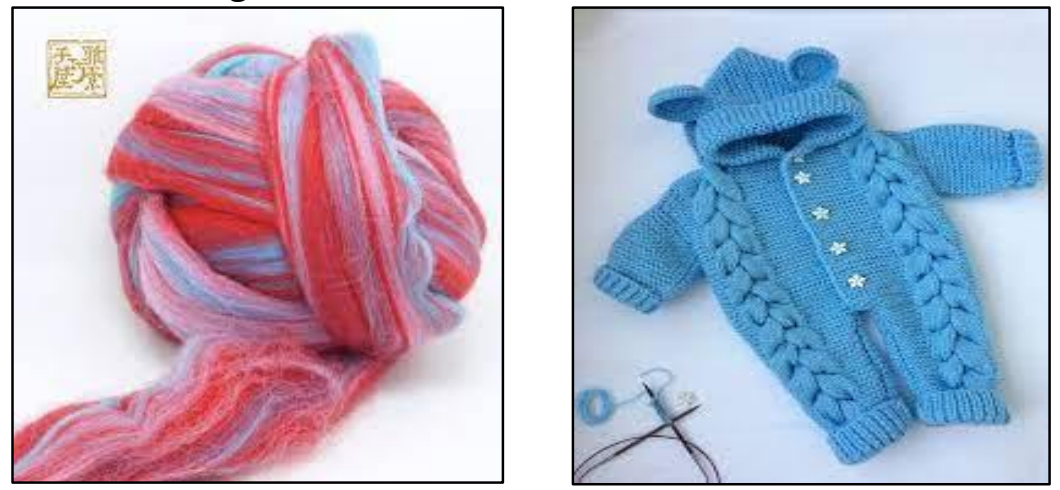

Figure 3. Wool and wool-made children's cloth

For making pre-school children's underwear is allowed that use cotton siblon ( $70 \%$ cotton and $30 \%$ siblon). In children's clothes, there should not be a kind of belt materials (the short's ribbon must be in the back).

In summer, because of climate, one and twolayered clothes are recommended. The first layer is white, the second for girls are a shirt, skirt and blouse, for boys is a shirt and shorts. 
Table 1. Mechanic features of drapery materials prepared in different amounts.

\begin{tabular}{|c|c|c|c|c|}
\hline \multirow{2}{*}{$\begin{array}{c}\text { Physic-hygienic } \\
\text { Indicators }\end{array}$} & \multicolumn{4}{|c|}{ Kinds of clothes } \\
\cline { 2 - 5 } & Optimal & Allowed & Optimal & Allowed \\
\hline 1 & 2 & 3 & 4 & 5 \\
\hline $\begin{array}{c}\text { Hygroscopic } \\
\text { relative humidity } \\
65 \%\end{array}$ & $7-9$ & $6-7$ & $7-8$ & \\
$100 \%$ & $20-30$ & $18-30$ & $18-30$ & $>100$ \\
Air & $>100$ & $>100$ & $\begin{array}{c}>150 \text { for } \\
\text { Natural fibre } \\
\text { materials }\end{array}$ & $\begin{array}{c}\text { Chemical fibre } \\
\text { materials }\end{array}$ \\
\hline \begin{tabular}{c} 
conductivity dm $3 / \mathrm{m}^{2}$ \\
\hline
\end{tabular} & & \multicolumn{3}{c}{}
\end{tabular}

Estimating heat-saving features of children's cloth.

The heat-saving features of children's cloth will be estimated based on the organism's total reactions. In this, children's energy use, amount of sweat released, respiratory rate and pulse detection, in addition, a questionnaire filled from children will be taken into account. All information about the heat saving feature of children's cloth will be taken from measuring body temperature and clarifying heat flow density. The density of heat scale is the loosen heat, by radiation and convection, amount during a unit of time. The cloth's heatsaving feature is decreasing the density of heat flow. Because of ambient temperature and feature of heat saving of children's cloth, heat flow changes.

\section{REFERENCES}

1. G.I.Shayxova. (2004). Bolalar va o'smirlar gigienasi. Toshkent tezkor bosmaxonasi.
2. Ulugboboyeva, M. M., \& Tursunova, X. S. (2021). Ways to solve problems in the production of knit wear. Asian Journal of Multidimensional Research, 10(9), 29-33.

3. Sharipov, S. (2020). Mehnat ta'limi o 'qitish metodikasi, kasb tanlashga yo 'llash. Архив Научных Публикаций JSPI.

4. Abdusattorovna, M. G., \& Qosimjonovna, U. N. (2020). Productan object of artistic thinking. ACADEMICIA: An International Multidisciplinary Research Journal, 10(11), 1172-1176.

5. Raxmatovna, M. S. (2021). The description of perspective fashion trends in men's clothing. Innovative Technologica: Methodical Research Journal, 2(10), 15-20.

6. Mamatqulova, S. R., Nurmatov, D. X. O., Ergashev, M. I. O., \& Moydinov, N. X. O. G. L. (2020). The influence of the qualification of repair workers on the efficiency of technical operation of automobiles. Science and Education, 1(9). 
7. Ismoilova, D. S., \& Mamatqulova, S. R. (2021). Improving the system of electrical equipment of cars on the basis of adaptive power converters. Science and Education, 2(2), 110-114.

8. Валиев, Г. Н., Хомидов, В. О., \& Турдиев, М. (2020). Особенности формы баллона нити натурального шёлка при сматывании с неподвижной паковки. Физика волокнистых материалов: структура, свойства, наукоемкие технологии и материалы (Smartex), (1), 24-29.

9. Mirboboeva, G.A., Urmonova, N.Q. (2021). Retro style in modeling women's clothing. Asian Journal of Multidimensional Research (AJMR), 10(9).

10. Zikirov, M. C., Qosimova, S. F., \& Qosimov, L. M. (2021). Direction of modern design activities. Asian Journal of Multidimensional Research (AJMR), 10(2), 11-18.

11. Орипов, Ж. И., \& Валиев, Г. Н. (2020). Исследование качественных характеристик шёлка-сырца механического и автоматического кокономотания. Физика волокнистых материалов: структура, свойства, наукоемкие технологии и материалы (SMARTEX), (1), 84-87.

12. Мирзахонов, М., \& Валиев, Г. Н. (2020). Разработка новой структуры плательно-костюмной ткани из натурального шелка Development of a new structure of dress-costume fabrik made of natural silk. In Сборник научных трудов Международной научной конференции, посвященной 110-летию со дня рождения профессора АГ Севостьянова (рр. 261-264).

13. Турдиев, М. (2020). Новая технология подготовки нитей основы к ткачеству при выработке тканей крепдешин New technology of preparing of basis threads for weaving in the production of crepe fabric. In Научная Конференция (р. 147).

14. Maxmudjon, T. (2021). The figurative expression of the composition of costume. Innovative Technologica: Methodical Research Journal, 2(10), 38-

42. 